\title{
MAPPING TINGKAT KERAWANAN COVID-19 DAN FAKTOR AKSELERATOR PENYEBARAN VIRUS ANTAR DAERAH DI INDONESIA DENGAN MENGGUNAKAN ANALISIS CLUSTER HIERARKI Studi Kasus Data COVID-19 di Indonesia
}

\author{
(Mapping of Vulnerability Level Covid-19 and Accelerator Factors In Indonesia Using \\ Hierarchical Cluster Analysis: Case Study of COVID-19 Data in Indonesia)
}

\author{
Nur Silviyah Rahmi ${ }^{1}$ \\ Universitas Brawijaya ${ }^{1}$ \\ Jl. Veteran, Malang 65145, INDONESIA \\ E-mail: silviyahrahmi@ub.ac.id
}

\begin{abstract}
ABSTRAK
Saat ini pandemi virus corona memaksa pemerintah untuk menyusun dan menerapkan kebijakankebijakan yang tidak biasa. Apalagi dampak dari pandemi ini tidak hanya dirasakan sektor kesehatan, namun juga memukul sektor-sektor lain seperti ekonomi, pendidikan, sosial, dan pariwisata. Untuk mencegah terjadinya dampak yang lebih besar perlu dilakukan pengelompokan daerah berdasarkan faktor-faktor yang menjadi akselerator penyebaran virus corona sehingga bisa disusun kebijakan-kebijakan yang tepat bagi tiap daerah. Hal tersebut dikarenakan kondisi demografi dan budaya antar daerah di Indonesia yang berbedabeda. Berdasarkan latar belakang tersebut, tujuan adanya penelitian ini yaitu untuk mengetahui peta tingkat kerawanan pandemi di setiap daerah yang disertai faktor akselerator penyebaran virus corona dengan menggunakan metode analisis cluster hierarki. Analisis cluster hierarki adalah teknik multivariat untuk mengelompokkan objek berdasarkan karakteristik yang dimilikinya. Analisis cluster mengklasifikasi objek sehingga setiap objek yang memiliki sifat yang mirip akan mengelompok kedalam satu cluster. Adapun faktor akselerator yang dimaksud adalah usia, kebiasaan cuci tangan, aktivitas kerja, dan aspek bepergian. Hasilnya menunjukkan bahwa dari 4 variabel akselerator penyebaran virus, terdapat daerah-daerah yang perlu diperhatikan. Provinsi Papua, Papua Barat, Riau, dan Kepulauan Riau masuk kategori aman, namun dari sisi faktor usia penduduk daerah-daerah tersebut masih tergolong waspada. Artinya jika faktor usia tidak diberikan perhatian khusus, ke empat provinsi tersebut berpotensi naik status menjadi waspada atau bahkan Rawan. Hasil dari analisis ini diharapkan menjadi informasi mengenai keadaan status kerawanan tiap daerah dan dapat dijadikan sebagai saran bagi pemerintah dalam mengambil kebijakan secara tepat.
\end{abstract}

Kata kunci: Virus Corona, Analisis Cluster Hierarki, Peta Kerawanan, Faktor Akselerator.

\section{ABSTRACT}

Currently the corona virus pandemic is forcing the government to formulate and implement unusual policies. Moreover, the impact of this pandemic was not only felt by the health sector, but also hit other sectors such as the economy, education, social and tourism. To prevent a bigger impact, it is necessary to group the regions based on the factors that accelerate the spread of the corona virus so that appropriate policies can be formulated for each region. It is because the demographic and cultural conditions between regions in Indonesia are different. Based on this background, the purpose of this research is to find out a map of the level of pandemic vulnerability in each area accompanied by the accelerator factor of the spread of the corona virus using the hierarchical cluster analysis method. Hierarchical cluster analysis is a multivariate technique for grouping objects based on their characteristics. Cluster analysis classifies objects so that each object that has similar properties will be grouped into one cluster. The accelerator factors referred are age, hand washing kebiasaans, work activities, and aspects of traveling. The results show that the 4 variables accelerating of the virus spread, are need attention. The provinces of Papua, West Papua, Riau, and Riau Islands are in the safe category, but from the age factor of the population, these areas are still classified as alert. This means that if the age factor is not given special attention, the four provinces have the potential to increase their status to be alert or even vulnerable. The results of this analysis are expected to provide information regarding the state of vulnerability of each region and can serve as suggestions for the government in making appropriate policies.

Keywords: Corona Virus, Hierarchical Cluster Analysis, Vulnerability Map, Accelerator Factors 


\section{PENDAHULUAN}

Pandemi virus corona telah menimbulkan dampak besar bagi negara Indonesia. Tidak hanya dirasakan oleh sektor kesehatan, tetapi pandemi juga memukul sektor-sektor lain seperti ekonomi, industri, pendidikan, sosial, dan pariwisata (Rohmah 2020). Dari segi wilayah, tidak ada satu pun provinsi di Indonesia yang tidak terdampak oleh virus corona dalam skala kecil maupun skala besar. Berbagai kebijakan telah dilakukan oleh pemerintah untuk mengantisipasi dan meminimalisir dampak dari pandemi. Seperti pembentukan tim satgas gugus tugas percepatan penanganan covid19, Pemberlakuan PSBB (Pembatasan Sosial Berskala Besar) di berbagai daerah (Arum 2020), pembelian alat tenaga kesehatan dan upgrade sejumlah rumah sakit rujukan pasien covid-19, penyaluran bantuan sosial berupa sembako dan uang tunai bagi masyarakat yang membutuhkan, pembebasan biaya listrik untuk golongan tertentu, dan pemberian kebijakan fiskal dan insentif pajak untuk sektor industri (Tapung et al. 2020). Namun, berbagai kebijakan tersebut masih belum memberikan dampak signifikan. Terutama di bidang kesehatan dan Ekonomi.

Persebaran virus corona sendiri berbeda-beda tiap daerah. Hal itu dikarenakan faktor yang mempercepat penyebaran virus kondisinya tidak sama. faktor tersebut diantaranya usia penduduk, kebiasaan cuci tangan dengan benar, tipe dan mobilitas pekerja, dan kebiasaan bepergian (Purnama and Susanna 2020). Keempat faktor tersebut selalu menjadi perhatian pemerintah dalam menyusun kebijakan. Sosialisasi rajin cuci tangan dan ajakan di rumah saja adalah contoh upaya pemerintah untuk menekan faktor-faktor yang menjadi akselrator penyebaran virus corona. Melihat kondisi geografis dan demografi wilayah Indonesia yang beragam, berbagai kebijakan yang telah dilakukan perlu dikaji lagi dengan memperhatikan kondisi dan faktor akselerator penyebaran corona tiap daerah. Agar berbagai kebijakan tersebut lebih efektif dan berdampak signifikan untuk memulihkan sektor-sektor yang telah terdampak. Pengelompokan (clustering) menjadi hal penting agar memudahkan dalam pemetaan kondisi yang pada akhirnya dapat melahirkan kebijakan yang tepat.

Analisis cluster hierarki adalah teknik multivariat untuk mengelompokkan objek berdasarkan karakteristik yang dimilikinya. Analisis cluster mengklasifikasi objek sehingga setiap objek yang memiliki sifat yang mirip akan mengelompok kedalam satu cluster. Dengan terbentuknya kelompokkelompok, identifikasi karakteristik kelompok mudah dilakukan sehingga diperoleh gambaran karakteristik setiap kelompok. Hal ini menjadi penting dilakukan guna melihat daerah-daerah mana saja yang membentuk kelompok dengan tingkat kerawanan beserta faktor-faktor didalamnya. Informasi ini dapat menjadi dasar bagi pemerintah dalam menentukan prioritas kebijakan. Berdasarkan uraian tersebut, penelitian ini bertujuan untuk memetakan provinsi di indonesia berdasarkan tingkat kerawanan pandemi beserta faktor-faktor yang menjadi akselerator persebaran virus corona menggunakan metode analisis cluster berhirarki.

\section{METODE}

Data yang digunakan pada penelitian ini adalah data kasus corona yang terkonfirmasi di seluruh provinsi se-Indonesia mulai 2 Maret 2020 sampai dengaan 24 Juni 2020. Data tersebut diakses berdasarkan keluaran resmi BPS (BPS 2020). Metode yang digunakan yaitu analisis cluster hierarki (Windarto et al. 2020) untuk memetakan tingkat kerawanan covid-19 (Yusup 2020) antar daerah yang disertai faktor akselerator penyebaran virus. Adapun faktor akselerator yang dimaksud adalah usia (Wulandari et al. 2020), kebiasaan cuci tangan (Br. Karo 2020), aktivitas kerja (Fahmy 2018), dan aspek bepergian (Chinazzi et al. 2020). Rincian variabel ditampilkan pada Tabel 1 berikut.

Tabel 1. Daftar Variabel Penelitian.

\begin{tabular}{cl}
\hline Variabel & \multicolumn{1}{c}{ Keterangan } \\
\hline $\mathrm{X} 1$ & Jumlah kasus Corona masing-masing provinsi di seluruh Indonesia \\
\hline $\mathrm{X} 2$ & Proporsi penduduk yang berusia 50 tahun ke atas menurut wilayah \\
\hline $\mathrm{X} 3$ & Proporsi penduduk yang mempunyai kebiasaan cuci tangan yang benar menurut wilayah \\
\hline $\mathrm{X} 4$ & $\begin{array}{l}\text { Proporsi Komuter (Pekerja Ulang Alik) dan tenaga kerja informal terhadap jumlah penduduk } \\
\text { menurut wilayah }\end{array}$ \\
\hline $\mathrm{X} 5$ & Persentase penduduk yang berpergian dengan jarak $\geq 100 \mathrm{Km}$ PP menurut wilayah \\
\hline
\end{tabular}


Metode yang digunakan yaitu Analisis cluster. Analisis Cluster merupakan metode dengan analisis peubah ganda untuk mengelompokkan $n$ objek kedalam $m$ cluster $(m \leqslant n)$ berdasarkan karakteristiknya. Pengelompokan dilakukan berdasarkan pada sifat kemiripan atau sifat ketidakmiripan antar objek. Objek yang berada dalam kelompok yang sama akan lebih mirip dibandingkan dengan objek antar kelompok. Jarak Euclid adalah jarak yang sering digunakan sebagai ukuran kemiripan atau ketidakmiripan antar objek. Menurut (A. R. Johnson and Wichern 2002) jarak Euclid didefinisikan sebagai berikut :

$d_{i j}=\left[\left(x_{i}-x_{j}\right)^{\prime}\left(x_{i}-x_{j}\right)\right]^{1 / 2}$

dimana:

$d_{i j} \quad=$ Jarak antara objek ke-i dan ke-j

$x_{i} \quad=$ Vektor peubah untuk objek ke-i

$x_{j} \quad=$ Vektor peubah untuk objek ke-j

Terdapat 2 metode pengklasteran, yaitu metode hirarki dan metode nonhirarki. Analisis cluster dengan metode hirarki adalah analisis yang pengclusteran datanya dilakukan dengan cara mengukur jarak kedekatan pada setiap obyek yang kemudian membentuk sebuah degdogram. Jenis analisis cluster dengan metode hirarki ada beberapa macam, diantaranya yaitu metode single linkage, metode complete linkage, metode Average Linkage, metode centroid, metode ward, dan metode median clustering. Pembentukan cluster hirarki mempunyai sifat sebagai pengembangan suatu hirarki atau struktur mirip pohon bercabang. Metode cluster hirarki merupakan metode pengelompokan yang mana jumlah kelompok yang akan dibuat belum diketahui. Teknik ini diproses dengan baik melalui penggabungan berurutan (agglomerative) atau pembagian berurutan (divissive).

Menurut (S. C. Johnson 1967), cara kerja metode cluster hirarki yaitu, diberikan sekumpulan N item yang akan di cluster, dan sebuah matrik $\mathrm{N}$ x $\mathrm{N}$ yang menyatakan jarak antar item pada $\mathrm{N}$ :

1. Mulai dengan membuat cluster sebanyak $\mathrm{N}$, masing-masing cluster mempunyai sebuah item. Misalnya jarak antar cluster sama dengan jarak antar item yang dikandungnya.

2. Cari sepasang cluster yang jaraknya terdekat, dan dijadikan sebuah cluster baru. Sehingga terdapat $\mathrm{N}-1$ cluster.

3. Hitung jarak antar cluster yang baru dengan masing-masing cluster yang lainnya.

Ulangi langkah 2 dan 3 sampai semua item menjadi sebuah cluster dengan $\mathrm{N}$ item. Tentunya tidak ada gunanya mempunyai $\mathrm{N}$ item yang dikelompokkan menjadi satu cluster besar.

Metode Average Linkage yaitu metode dengan cara menghitung jarak dua cluster yang disebut sebagai jarak rata-rata yang mana menurut (A. R. Johnson and Wichern 2002) jarak tersebut dihitung pada masing-masing cluster oleh persamaan berikut:

$d_{(U V) W}=\frac{\Sigma_{i} \Sigma_{k} d_{i k}}{N_{(U V)} N_{W}}$

dimana:

$d_{i j} \quad=$ Jarak antar objek i dalam cluster (UV) dan objek $\mathrm{k}$ dalam cluster $\mathrm{W}$

$N_{(U V)}=$ Jumlah objek dalam cluster (UV)

$N_{W}=$ Jumlah objek dalam cluster $\mathrm{W}$

\section{HASIL DAN PEMBAHASAN}

Tercatat pada bulan ke-3 sejak pertama kasus corona terkonfirmasi, pandemi corona telah menyebar ke seluruh provinsi di Indonesia. Jumlah kasus corona yang paling banyak terkonfirmasi di provinsi DKI Jakarta yaitu sebanyak 10.250 kasus. Provinsi Jawa Timur dan Sulawesi Selatan menempati urutan ke-2 dan ke-3 dalam kaitan jumlah kasus corona paling banyak dengan jumlah masing-masing 10.115 kasus dan 4.062 kasus. Total 3 daerah tersebut menyumbang 51,31\% dari jumlah kasus corona di seluruh negara Indonesia. Sedangkan untuk daerah dengan jumlah kasus corona terendah adalah provinsi D.I Yogyakarta dan Aceh yaitu 0 kasus dan 49 kasus. Secara 
kumulatif angka kasus corona Kedua provinsi tersebut selama 3 bulan terakhir tercatat masih dibawah angka 100 kasus.

Selanjutnya, gambaran faktor akselerator penyebaran virus corona dapat dilihat di Gambar 1. Angka proporsi rata-rata penduduk usia tua di seluruh provinsi adalah $19.40 \%$ dari total penduduk. Hal tersebut menunjukkan bahwa penduduk yang beresiko tinggi terpapar virus corona masih cukup besar. Rata-rata proporsi penduduk yang mempunyai kebiasaan cuci tangan dengan benar adalah 46.49\%. Artinya lebih dari 50\% penduduk masih belum mempunyai kebiasaan cuci tangan dengan benar. Hal tersebut sangat perlu diperhatikan, karena cuci tangan merupakan salah satu cara paling utama untuk memutus rantai penyebaran virus corona. Selanjutnya, rata-rata proporsi penduduk dengan Type pekerja informal dan model kerjanya komuter adalah sebesar $28.41 \%$ dan rata-rata proporsi penduduk yang memiliki kebiasaan bepergian (travel) adalah sebesar $26.02 \%$. Kedua angka tersebut menunjukkan bahwa mobilitas pekerja dan taveller masih cukup tinggi dan menjadi salah satu pemicu persebaran virus corona antar daerah.

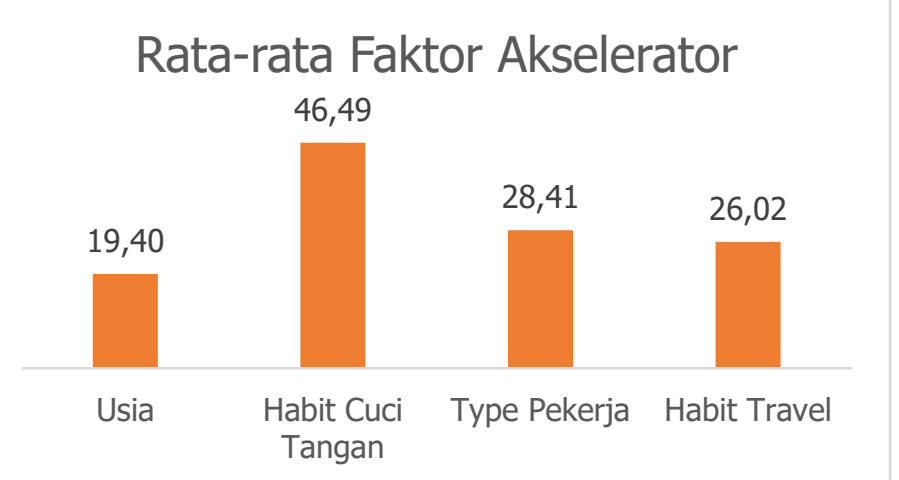

Gambar 1. Rata-rata Faktor Akselerator di Seluruh Provinsi di Indonesia.

Kemudian, melalui diagram kotak garis (Gambar 2) ditampilkan informasi tentang gambaran masing-masing variabel akselerator penyebaran virus corana untuk semua propinsi. Variabel Kebiasaan Cuci Tangan dan Kebiasaan Travel memiliki ragam yang besar. Sedangkan variabel Usia dan Type Pekerja memiliki ragam yang kecil. Variabel Kebiasaan Cuci Tangan memiliki ragam terbesar dibandingkan variabel lainnya dan variabel dengan ragam terkecil yaitu Variabel Usia. Terlihat bahwa dari beberapa variabel terdapat pencilan. Provinsi D.I Yogyakarta, Jawa Tengah, dan Jawa Timur merupakan pencilan untuk variabel usia dengan nilai yang lebih besar dibandingkan dengan provinsi lainnya. Provinsi Kepulauan Riau merupakan pencilan untuk variabel Type Pekerja dengan nilai yang lebih kecil dibandingkan dengan provinsi lainnya. Provinsi D.I Yogyakarta merupakan pencilan untuk variabel Kebiasaan Travel dengan nilai yang lebih besar dibandingkan dengan provinsi lainnya.

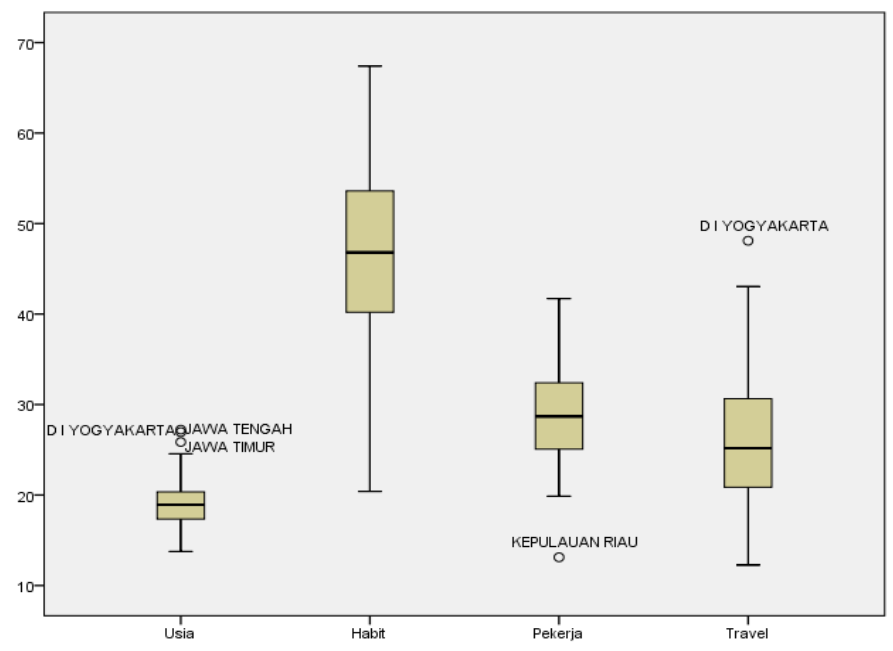

Gambar 2. Sebaran provinsi di Indonesia untuk tiap faktor Akselerator. 
Selanjutnya melakukan analisis cluster hirarki untuk mengelompokkan status kerawanan penyebaran covid terhadap keempat faktor akselerator. Analisis cluster hirarki merupakan suatu metode yang tidak membutuhkan asumsi karena dibuat kedalam jumlah kelompok atau struktur kelompok. Analisis cluster hirarki sendiri merupakan suatu metode pengelompokan yang jumlah kelompok yang akan dibuat belum diketahui. Analisis ini menggunakan metode cluster hirarki yaitu metode Average Linkage. Average Linkage merupakan salah satu metode cluster hirarki yang didasarkan pada rata-rata jarak jauh dari seluruh objek pada suatu cluster dengan seluruh objek pada cluster lain. Proses pengclusteran dapat dilakukan dengan SPSS, yaitu dengan tahap agglomerasi sebagai berikut:

1. Jumlah kasus penyebaran Virus Corona menurut wilayah

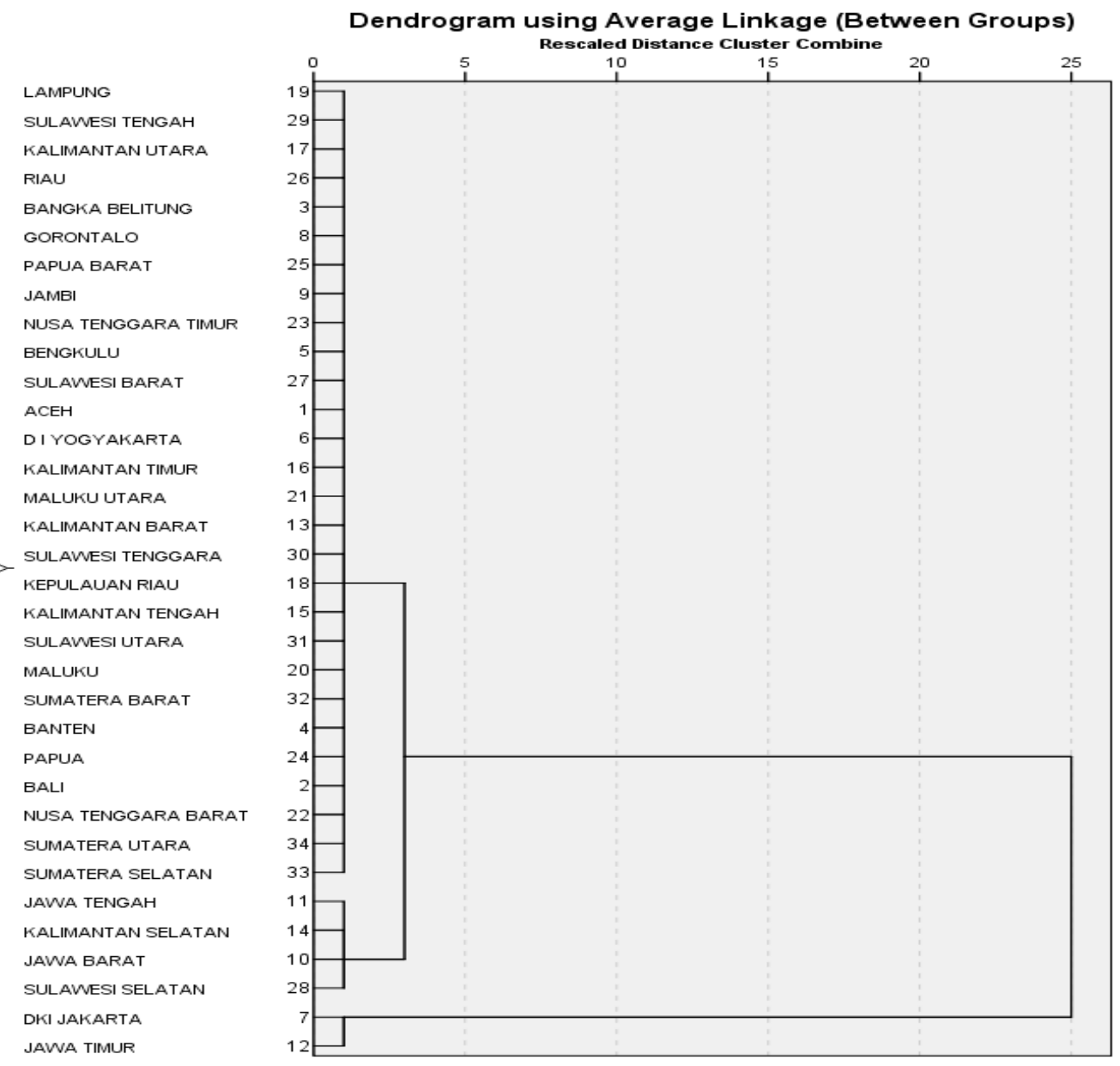

Gambar 3. Dendogram Jumlah kasus corona menurut wilayah.

Hasil pada Gambar 3 menunjukkan bahwa hasil pengelompokan dengan metode Average Linkage untuk jumlah kasus corona diperoleh 3 kelompok, dengan kelompok 1 terdapat 28 provinsi yang merupakan wilayah aman dengan jumlah kasus corona rendah, kelompok 2 terdapat 4 provinsi yang merupakan wilayah waspada dengan jumlah kasus corona sedang dan kelompok 3 terdapat 2 provinsi yang merupakan wilayah rawan dengan jumlah kasus corona tinggi.

2. Proporsi penduduk usia tua menurut wilayah

Hasil pengelompokan dengan metode average linkage untuk proporsi penduduk usia tua ( $>$ 50th) diperoleh 3 kelompok, dengan kelompok 1 terdapat 4 provinsi yang merupakan wilayah dengan proporsi penduduk usia tua jumlahnya kecil, kelompok 2 terdapat 25 provinsi yang merupakan wilayah dengan proporsi penduduk usia tua jumlahnya sedang dan kelompok 3 terdapat 5 provinsi yang merupakan wilayah proporsi penduduk usia tua jumlahnya besar.

3. Proporsi penduduk yang memiliki kebiasan cuci tangan dengan benar menurut wilayah Hasil pengelompokan dengan metode average linkage untuk penduduk yang memiliki kebiasan cuci tangan dengan benar diperoleh 3 kelompok, dengan kelompok 1 terdapat 28 provinsi yang merupakan wilayah dengan angka proporsi penduduk yang memiliki kebiasaan cuci tangan yang benar masih sedang, kelompok 2 terdapat 2 provinsi yang merupakan wilayah dengan angka 
proporsi penduduk yang memiliki kebiasaan cuci tangan yang benar cukup tinggi dan kelompok 3 terdapat 4 provinsi yang merupakan wilayah dengan angka proporsi penduduk yang memiliki kebiasaan cuci tangan yang benar masih rendah.

4. $\quad$ Proporsi type pekerja penduduk menurut wilayah

Hasil pada Gambar 7 menunjukkan bahwa hasil pengelompokan dengan metode average linkage untuk proporsi penduduk yang bepergian diperoleh 3 kelompok, dengan kelompok 1 terdapat 20 provinsi yang merupakan wilayah dengan proporsi penduduk yang bepergian masih rendah kelompok 2 terdapat 11 provinsi yang merupakan wilayah dengan proporsi penduduk yang bepergian masih normal dan kelompok 3 terdapat 2 provinsi yang merupakan wilayah dengan proporsi penduduk yang bepergian cukup tinggi.

\section{Crosstab hasil pengelompokan analisis cluster}

Hasil pengelompokan provinsi-provinsi di Indonesia berdasarkan indikator jumlah kasus corona dan faktor-faktor akselerator masing-masing diperoleh 3 cluster. Selanjutnya hasil cluster metode hierarki akan ditabulasi silang untuk mendapatkan gambaran lebih lengkap masing-masing provinsi dengan pendekatan jumlah kasus corona dan factor-faktor akseleratornya.

Tabel 2. Pengelompokan wilayah berdasarkan jumlah kasus corona dan faktor akselerator.

\begin{tabular}{|c|c|c|c|c|c|c|}
\hline No & Provinsi & Kategori & Usia & $\begin{array}{c}\text { Kebiasaan cuci } \\
\text { tangan }\end{array}$ & $\begin{array}{c}\text { Pekerja ulak- } \\
\text { alik }\end{array}$ & $\begin{array}{c}\text { Aspek } \\
\text { bepergian }\end{array}$ \\
\hline 1 & Aceh & \multirow{28}{*}{ Aman } & Waspada & Rendah & Normal & Rendah \\
\hline 2 & Maluku Utara & & Waspada & Rendah & Normal & Rendah \\
\hline 3 & Nusa Tenggara Timur & & Waspada & Rendah & Normal & Rendah \\
\hline 4 & Kalimantan Utara & & Waspada & Tinggi & Normal & Rendah \\
\hline 5 & Bengkulu & & Waspada & Sedang & Normal & Rendah \\
\hline 6 & Jambi & & Waspada & Sedang & Normal & Rendah \\
\hline 7 & Kalimantan Barat & & Waspada & Sedang & Normal & Rendah \\
\hline 8 & Kalimantan Tengah & & Waspada & Sedang & Normal & Rendah \\
\hline 9 & Kalimantan Timur & & Waspada & Sedang & Normal & Rendah \\
\hline 10 & Lampung & & Waspada & Sedang & Normal & Rendah \\
\hline 11 & Maluku & & Waspada & Sedang & Normal & Rendah \\
\hline 12 & Nusa Tenggara Barat & & Waspada & Sedang & Normal & Rendah \\
\hline 13 & Sulawesi Barat & & Waspada & Sedang & Normal & Rendah \\
\hline 14 & Sulawesi Tengah & & Waspada & Sedang & Normal & Rendah \\
\hline 15 & Sumatera Selatan & & Waspada & Sedang & Normal & Rendah \\
\hline 16 & Sumatera Utara & & Waspada & Sedang & Normal & Rendah \\
\hline 17 & Banten & & Waspada & Sedang & Normal & Normal \\
\hline 18 & Bangka Belitung & & Waspada & Sedang & Normal & Normal \\
\hline 19 & Gorontalo & & Waspada & Sedang & Normal & Normal \\
\hline 20 & Sulawesi Tenggara & & Waspada & Sedang & Normal & Normal \\
\hline 21 & Sumatera Barat & & Waspada & Sedang & Normal & Normal \\
\hline 22 & Bali & & Rawan & Tinggi & Normal & Normal \\
\hline 23 & Sulawesi Utara & & Rawan & Sedang & Normal & Rendah \\
\hline 24 & D I Yogyakarta & & Rawan & Sedang & Normal & Tinggi \\
\hline 25 & Papua & & Aman & Rendah & Tinggi & Rendah \\
\hline 26 & Papua Barat & & Aman & Sedang & Normal & Rendah \\
\hline 27 & Riau & & Aman & Sedang & Normal & Rendah \\
\hline 28 & Kepulauan Riau & & Aman & Sedang & Rendah & Normal \\
\hline 29 & Sulawesi Selatan & \multirow{4}{*}{ Waspada } & Waspada & Sedang & Normal & Rendah \\
\hline 30 & Jawa Barat & & Waspada & Sedang & Normal & Normal \\
\hline 31 & Kalimantan Selatan & & Waspada & Sedang & Normal & Normal \\
\hline 32 & Jawa Tengah & & Rawan & Sedang & Normal & Normal \\
\hline 33 & Jakarta & \multirow{2}{*}{ Rawan } & Rawan & Sedang & Normal & Tinggi \\
\hline 34 & Jawa Timur & & Rawan & Sedang & Normal & Normal \\
\hline
\end{tabular}


Berdasarkan Tabel 2, dari 34 provinsi di seluruh Indonesia, terdapat 82,35\% (28 provinsi) yang termasuk dalam kategori Aman (Satria, Hasanah, and Rudiansyah 2020). Apabila diamati lebih lanjut, penyebaran virus pada Provinsi Papua, Papua Barat, Riau, dan Kepulauan Riau termasuk pada kategori aman. Namun dari faktor usia, status daerah tersebut tergolong waspada. Artinya jika faktor usia tidak diberikan perhatian khusus, maka berpotensi naik status menjadi waspada atau bahkan Rawan. Dari faktor kebiasaan cuci tangan, terdapat 4 provinsi yang kebiasaan cuci tangan masyarakatnya masih tergolong rendah. Keempat provinsi tersebut adalah Aceh, Maluku Utara, Nusa Tenggara Timur, dan Papua. Kebiasaan cuci tangan yang rendah tentu berpotensi mempercepat penyebaran virus.

Kemudian dari faktor Pekerja ulak-alik dan proporsi masyarakat dengan jenis pekerjaan informal. Terdapat 1 provinsi yang faktor Pekerja ulak-aliknya tergolong tinggi yaitu kepulauan Riau. Kebijakan di sektor industri dan ketenagakerjaan tentu menjadi sangat penting agar tetap menjadi provinsi dengan kategori aman. Selanjutnya dari sisi Aspek bepergian terdapat 7 daerah yang tergolong memiliki Aspek bepergian tinggi. Ketujuh daerah tersebut adalah Banten, Bangka Belitung, Gorontalo, Sulawesi Tenggara, Sumatera Barat, Bali, dan Kepulauan Riau. Faktor Aspek bepergian yang tinggi akan menjadi akserator bagi penyebaran virus. Sehingga ketujuh provinsi tersebut butuh kebijakan khusus di sektor sosial.

Berdasarkan tabel 2 juga dapat diketahui bahwa sebesar 11,76 persen dari total provinsi di daerah Indonesia masuk dalam kategori Waspada. Daerah-daerah tersebut adalah Sulawesi Selatan, Jawa Barat, Kalimantan Selatan, dan Jawa Tengah. Keempat daerah terebut harus diberikan kebijakan khusus agar bisa turun status menjadi aman. Jika dilihat dari faktor akselerator, Jawa Tengah memiliki faktor usia rawan dan aspek bepergian tinggi yang perlu diantisipasi dengan kebijakan khusus. Jawa Barat dan Kalimantan Selatan tergolong daerah dengan aspek bepergian yang tinggi, sehingga kedua daerah itu perlu kebijakan khusus di Bidang Sosial, misalnya PSBB (Pembatasan Sosial Berskala Besar) (Nasruddin and Haq 2020).

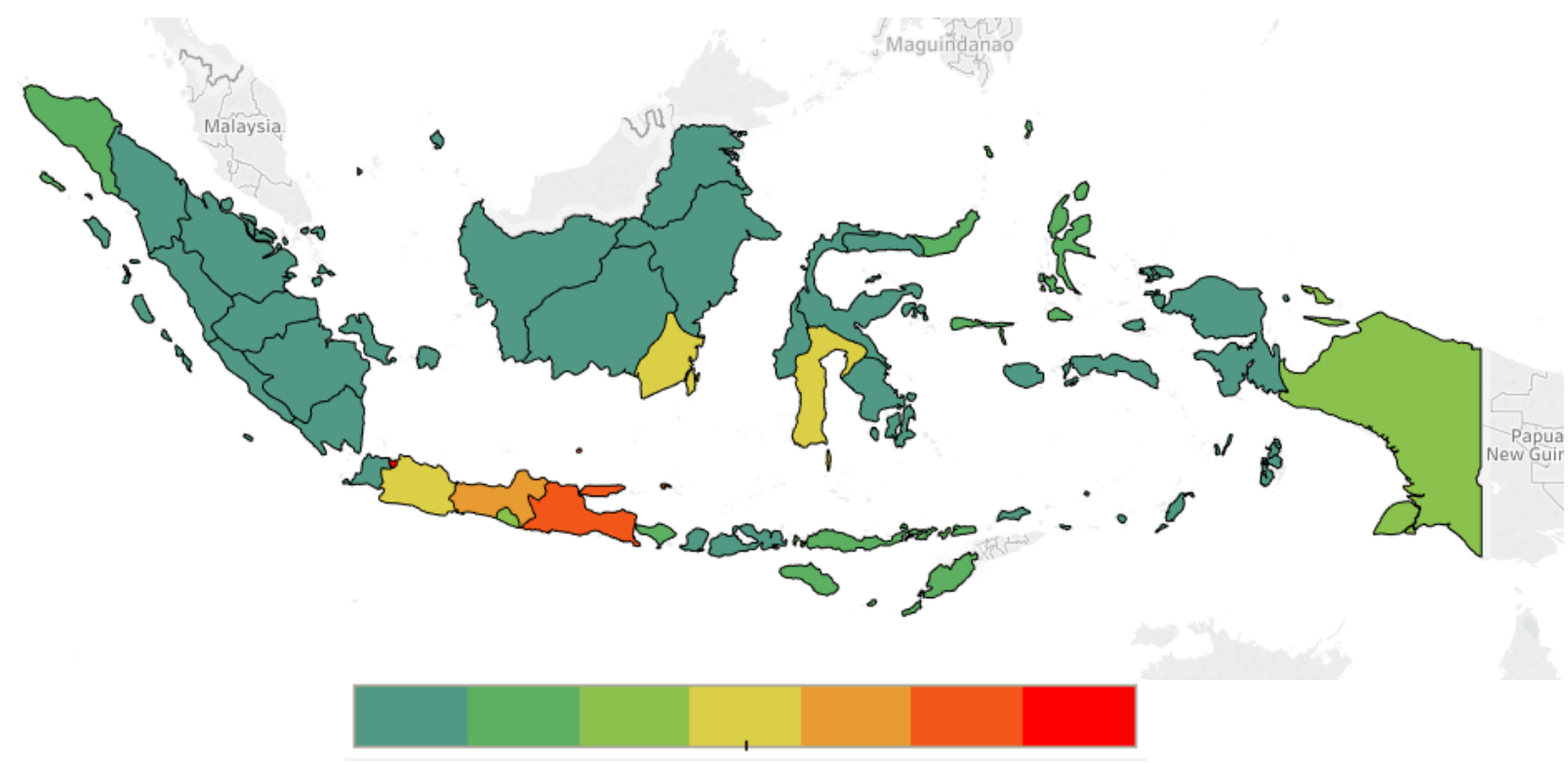

Gambar 4. Dendogram Jumlah kasus corona menurut wilayah.

\section{KESIMPULAN}

Hasil pengelompokan berdasarkan jumlah kasus corona diperoleh 3 (tiga) cluster. Cluster pertama terdiri dari 28 provinsi yang memiliki karakteristik jumlah kasus corona masih rendah atau berkatogori aman. Cluster kedua terdiri dari 4 provinsi yang memiliki karakteristik jumlah kasus corona cukup tinggi atau berkatogori waspada. Cluster ketiga terdiri dari 2 provinsi yang memiliki karakteristik jumlah kasus corona sangat tinggi atau berkatogori rawan. Kemudian, dari 28 provinsi yang berkategori aman terdapat 3 daerah yang berpotensi naik status menjadi waspada atau rawan 
karena memiliki angka faktor akselerator penyebaran corona yang tinggi. Provinsi Bali, Sulawesi Utara, dan D.I Yogyakarta bisa menjadi naik status karena faktor proporsi penduduk usia lanjut. Provinsi Aceh, Maluku Utara, Nusa Tenggara Timur, dan Papua juga dapat berubah status karena faktor proporsi penduduk yang memiliki kebiasaan cuci tangan dengan benar. Provinsi Papua menjadi satu-satunya daerah yang bisa menjadi rawan karena karena faktor proporsi penduduk dengan jenis pekerjaan ulang alik. Provinsi D.I Yogyakarta menjadi daerah yang bisa menjadi rawan karena karena faktor proporsi pendududuk yang memiliki kebiasaan bepergian. Selanjutnya dari 4 daerah yang masuk kategori waspada, tercatat ada 1 daerah yang berpotensi menjadi rawan karena memiliki faktor akselerator persebaran corona cukup tinggi untuk faktor usia. Daerah tersebut adalah provinsi Jawa Tengah. Daerah DKI Jakarta dan Jawa Timur yang berkategori rawan dapat menjadi lebih rawan jika tidak diberikan perhatian khusus. Hal ini dikarenakan DKI Jakarta dan Jawa timur memiliki faktor akselerator tergolong tinggi untuk faktor proporsi jumlah penduduk yang berusia lanjut dan proporsi penduduk dengan kebiasaan bepergian

\section{DAFTAR PUSTAKA}

Arum, Riska. 2020. Pembatasan Sosial Di Indonesia Akibat Virus Corona Ditinjau Dari Sudut Pandang Politik. LawArXiv. preprint. https://osf.io/g8ny3 (September 15, 2020).

BPS. 2020. "Hasil Survei Sosial Demografi Dampak Covid-19 2020 Badan Pusat Statistik." https://www.bps.go.id/publication/2020/06/01/effd7bb05be2884fa460f160/tinjauan-big-data-terhadapdampak-covid-19-2020.html (August 16, 2020).

Br. Karo, Marni. 2020. "Perilaku Hidup Bersih Dan Sehat (PHBS) Strategi Pencegahan Penyebaran Virus Covid19." http://proceedings.ideaspublishing.co.id/index.php/hardiknas/article/view/1 (August 16, 2020).

Chinazzi, Matteo et al. 2020. "The Effect of Travel Restrictions on the Spread of the 2019 Novel Coronavirus (COVID-19) Outbreak." https://science.sciencemag.org/content/368/6489/395.abstract (August 16, 2020).

Fahmy, Rifqi Nur. 2018. "Determinan Keputusan Melakukan Migrasi Ulang-Alik." Efficient: Indonesian Journal of Development Economics 242-51. https://journal.unnes.ac.id/sju/index.php/efficient/article/view/27869 (August 16, 2020).

Johnson, A. Richard, and Dean W Wichern. 2002. "Applied Multivariate Statistical Analysis, 6th Edition." https://www.pearson.com/us/higher-education/program/Johnson-Applied-Multivariate-StatisticalAnalysis-6th-Edition/PGM274834.html (September 15, 2020).

Johnson, Stephen C. 1967. "Hierarchical Clustering Schemes." Psychometrika 32(3): 241-54. https://doi.org/10.1007/BF02289588 (September 15, 2020).

Nasruddin, Rindam, and Islamul Haq. 2020. "Pembatasan Sosial Berskala Besar (PSBB) Dan Masyarakat Berpenghasilan Rendah." SALAM: Jurnal Sosial dan Budaya Syar-i 7(7): 639-48. http://103.229.202.71/index.php/salam/article/view/15569 (August 16, 2020).

Purnama, Sang Gede, and Dewi Susanna. 2020. "Hygiene and Sanitation Challenge for COVID-19 Prevention in Indonesia." Kesmas: Jurnal Kesehatan Masyarakat Nasional (National Public Health Journal) 15(2). http://journal.fkm.ui.ac.id/kesmas/article/view/3932 (September 15, 2020).

Rohmah, Siti Ngainnur. 2020. "Adakah Peluang Bisnis Di Tengah Kelesuan Perekonomian Akibat Pandemi Corona?" 'ADALAH 4(1). http://journal.uinjkt.ac.id/index.php/adalah/article/view/15448 (September 15, 2020).

Satria, Bambang Ari, Nur Hidayatul Hasanah, and Rudiansyah Rudiansyah. 2020. "Penyuluhan Adaptasi Tatanan Kebiasaan Baru Desa Tangguh Covid-19." http://ojs.uho.ac.id/index.php/anoa/article/view/13242 (August 16, 2020).

Tapung, Marianus Mantovanny et al. 2020. "Bantuan Sosial Dan Pendidikan Kesehatan Bagi Masyarakat Pesisir Yang Terdampak Sosial-Ekonomi Selama Patogenesis Covid-19 Di Manggarai." Transformasi: Jurnal Pengabdian Masyarakat 16(1): 12-26. https://journal.uinmataram.ac.id/index.php/transformasi/article/view/2067 (September 15, 2020).

Windarto, Agus Perdana, Ulfah Indriani, Mokhamad Ramdhani Raharjo, and Linda Sari Dewi. 2020. "Kombinasi Metode Klastering Dan Klasifikasi (Kasus Pandemi Covid-19 Di Indonesia)." JURNAL MEDIA INFORMATIKA BUDIDARMA 4(3): 855-62. https://ejurnal.stmik-budidarma.ac.id/index.php/mib/article/view/2312 (August 16, 2020). 
Wulandari, Anggun et al. 2020. "Hubungan Karakteristik Individu Dengan Pengetahuan Tentang Pencegahan Coronavirus Disease 2019 Pada Masyarakat Di Kalimantan Selatan." Jurnal Kesehatan Masyarakat Indonesia 15(1): 42-46. http://103.97.100.145/index.php/jkmi/article/view/5837 (August 16, 2020).

Yusup, Oleh Ari. 2020. "Pemetaan Sebaran, Potensi dan Kerentanan Pandemi Covid-19 Di Kecamatan Lembang Kabupaten Bandung Barat." : 15. 